\title{
EXISTENCE THEORY FOR NONLINEAR STURM-LIOUVILLE PROBLEMS WITH NON-LOCAL BOUNDARY CONDITIONS
}

\section{DANiEl MARONCELli AND Jesús RodRÍGUEZ}

Abstract. In this work we provide conditions for the existence of solutions to nonlinear SturmLiouville problems of the form

$$
\left(p(t) x^{\prime}(t)\right)^{\prime}+q(t) x(t)+\lambda x(t)=f(x(t))
$$

subject to non-local boundary conditions

$$
a x(0)+b x^{\prime}(0)=\eta_{1}(x) \text { and } c x(1)+d x^{\prime}(1)=\eta_{2}(x) .
$$

Our approach will be topological, utilizing Schaefer's fixed point theorem and the LyapunovSchmidt procedure.

Mathematics subject classification (2010): 34B24.

Keywords and phrases: Existence theory, Sturm-Liouville problem, boundary conditions.

\section{REFERENCES}

[1] A. BOUCHERIF, Second-order boundary value problems with integral boundary conditions, Nonlinear Anal. 70 (2009), 364-371.

[2] X. Chen And Z. Du, Existence of Positive Periodic Solutions for a neutral delay predator-prey model with Hassell-Varley type functional response and impulse, Qual. Theory Dyn. Syst., (2017), doi:10.1007/s12346-017-0223-6.

[3] S. Chow And J. K. Hale, Methods of Bifurcation Theory, Springer, Berlin, 1982.

[4] P. DRÁBEK, On the resonance problem with nonlinearity which has arbitrary linear growth, J. Math. Anal. Appl. 127 (1987), 435-442.

[5] P. DRÁBEK, Landesman-Lazer type condition and nonlinearities with linear growth, Czechoslovak Math. J. 40 (1990), 70-86.

[6] P. DrábeK And S. B. Robinson, Resonance problems for the p-laplacian, J. Funct. Anal. 169 (1999), 189-200.

[7] Z. I. DU AND J. Y IN, A Second Order Differential Equation with Generalized Sturm-Liouville Integral Boundary Conditions at Resonance, Filomat 28 (2014), 1437-1444.

[8] R. IANNACCI AND M. N. NkAShama, Nonlinear two point boundary value problems without Landesman-Lazer condition, Proc. Amer. Math. Soc. 106 (1989), 943-952.

[9] W. G. Kelley And A. C. Peterson, The theory of differential Equations, Springer, 2010.

[10] R. A. KHAN, The generalized method of quasilinearization and nonlinear boundary value problems with integral boundary conditions, Electronic. J. Qual. Theory Differ. Equ. 19 (2003), 1-15.

[11] E. M. LANDESMAN AND A. C. LAZER, Nonlinear perturbations of linear elliptic boundary value problems at resonance, J. Math. Mech. 19 (1969), 609-623.

[12] A. C. LAZER AND D. F. LEACH, Bounded perturbations of forced harmonic oscillators at resonance, Ann. Mat. Pure Appl. 82 (1969), 49-68.

[13] X. LIN AND Q. ZHANG, Existence of solution for a p-Laplacian multi-point boundary value problem at resonance, Qual. Theory Dyn. Syst., (2017), doi:10.1007/s12346-017-0259-7.

[14] R. MA, Nonlinear discrete Sturm-Liouville problems at resonance, Nonlinear Anal. 67 (2007), 3050 3057. 
[15] D. Maroncelli ANd J. RodrígueZ, Existence theory for nonlinear Sturm-Liouville problems with unbounded nonlinearities, Differ. Equ. Appl. 6 (2014), 455-466.

[16] D. MARONCELli AND J. RODRÍGUEZ, On the solvability of nonlinear impulsive boundary value problems, Topol. Methods Nonlinear Anal. 44 (2014), 381-398.

[17] H. PANG AND Y. TONG, Symmetric positive solutions to a second-order boundary value problem with integral boundary conditions, Bound. Value Probl. 150 (2013), 1-9.

[18] Jesús F. RodríGueZ, Existence theory for nonlinear eigenvalue problems, Appl. Anal. 87 (2008), 293-301.

[19] J. RodríGueZ, Nonlinear discrete Sturm-Liouville problems, J. Math. Anal. Appl. 308 (2005), 380391.

[20] J. RODRÍGUEZ AND A. SUAREZ, Existence of solutions to nonlinear boundary value problems, Differ. Equ. Appl. 9 (2017), 1-11.

[21] J. RodRÍGUEZ AND A. SuAREZ, On nonlinear perturbations of Sturm-Liouville problems in discrete and continuous settings, Differ. Equ. Appl. 8 (2016), 319-334.

[22] J. RodrígueZ ANd Z. AbernAthy, On the solvability of nonlinear Sturm-Liouville problems, J. Math. Anal. Appl. 387 (2012), 310-319.

[23] X. M. Zhang AND W. G. GE, Positive solutions for a class of boundary-value problems with single integral boundary conditions, Computers Mathematics with Applications 58 (2009), 203-215. 